
університету. - Серія "Регіональна економіка". - Випуск 15 (59). - Редкол.: відп. ред. д.е.н., професор Л.Л. Ковальська. - Луиьк: ІВВ Луиького НТУ, 2018. - 292 с.

\author{
УДК 338.22.021.1:332.13: 334.021.1
}

Бондарук Х.В., асистент

Луцький національний технічний університет

\title{
СУТНІСТЬ ТА ЗНАЧЕННЯ СОЦІАЛЬНОГО ПІДПРИЄМНИЦТВА В РЕГІОНАЛЬНІЙ ЕКОНОМІЦІ
}

У статті проаналізовано сутність соціального підприємництва та ефекти впливу від такої діяльності на регіональну економіку. Обгрунтовано поняття соціального підприємництва, здійснено порівняльну оцінку соціального підприємства, благодійної організації та підприємництва, виокремлені ефекти від діяльності соціального підприємства та його вплив на регіональний розвиток.

Ключові слова: соціальне підприємництво, соціальний ефект, цілі соціального підприємництва, економічний ефект, екологічний ефект, регіональна економіка.

Bondaruk K.

\section{ESSENCE AND SIGNIFICANCE OF SOCIAL ENTERPRISES IN REGIONAL ECONOMY}

The article analyses the essence of social entrepreneurship and the effects of such activity on the regional economy. The concept of social entrepreneurship is substantiated, a comparative assessment of social enterprise, charitable organization and entrepreneurship is made, the effects of social enterprise activity and its influence on regional development are singled out.

Social entrepreneurs recognize the social problem in a certain area (OTG, city, region) and organize enterprise management in order to address specific social problems. They contribute to meeting the needs of the population, even if there is no or insufficient number of resources, the awareness of the need to address the social problems of the economic region is of vital importance. Social entrepreneurship has a significant impact on the social development of the region and the country, but the economic effect also plays an important role. Social entrepreneurship through the implementation of cultural, economic and political changes plays an important role for society and serves the improvement of socio-economic development.

The social mission is fundamental to social entrepreneurship, since it recognizes and assesses the potential of social development. And the work of a social entrepreneur is to identify and solve problems by changing the stereotypes of the social system. Accordingly, the realization of the mission of social entrepreneurship in a certain territory will lead to the strengthening of social processes, the interaction of which will create a synergistic social effect in the creation, distribution, exchange and consumption of GDP.

A modern social entrepreneur carries out his activities in order to achieve a social 
Економічні науки: збірник наукових праџь Луцького національного технічного університету. - Серія "Регіональна економіка". - Випуск 15 (59). - Редкол.: відп. ред. д.е.н., професор Л.Л. Ковальська. - Луцьк: ІВВ Луцького НТУ, 2018. - 292 с.

effect, the solution of regional and state problems. Social entrepreneurs in the region carry out activities taking into account socio-economic interests and needs of the population and the community. Social entrepreneurship from philanthropy gets similarity to the social orientation of activity, and from business - an entrepreneurial approach and the possibility of profit for reinvestment of innovations.

Key words: social entrepreneurship, aims of social enterprise, social effect, economic effect, ecological effect, regional economy.

Бондарук К.В.

\section{СУЩНОСТЬ И ЗНАЧЕНИЕ СОЦИАЛЬНОГО ПРЕДПРИНИМАТЕЛЬСТВА В РЕГИОНАЛЬНОЙ ЭКОНОМИКЕ}

В статье проанализированы сущность социального предпринимательства и эффекты воздействия от такой деятельности на региональную экономику. Обосновано понятие социального предпринимательства, осуществлена сравнительная оценка социального предприятия, благотворительной организации и предпринимательства, выделены эффекты от деятельности социального предприятия и его влияние на региональное развитие.

Ключевые слова: социальное предпринимательство, цели социального предпринимательства, социальный эффект, экономический эффект, экологический эффект, региональная экономика.

Постановка проблеми у загальному вигляді та її зв'язок 3 важливими науковими та практичними завданнями. Розвиток соціального підприємництва $€$ важливим чинником підвищення економічного розвитку регіону та суспільного благополуччя населення. Діяльність соціального підприємства на певній території сприяє зростанню інноваційності в процесах прийняття управлінських рішень, зниженню рівня безробіття, прискоренню розвитку регіональної економіки.

В умовах невизначеності, загостренні соціальноекономічних проблем, проведенні структурних змін в економіці, ідея соціального підприємництва потребує залучення відповідних продуктивних сил, що в свою чергу потребує удосконалення методичних підходів до управління соціальним підприємництвом в регіонах.

Аналіз останніх досліджень, у яких започатковано вирішення проблеми. Завдяки соціальному підприємництву 

університету. - Серія "Регіональна економіка". - Випуск 15 (59). - Редкол.: відп. ред. д.е.н., професор Л.Л. Ковальська. - Луиьк: ІВВ Луиького НТУ, 2018. - 292 с.

підприємці реалізовують основну діяльність із створенням та відтворенням соціальної цінності у доданій вартості регіону без отримання прибутку на особисте споживання. Як зазначає Г. Діс, соціальний підприємець не має на меті отримання особистої вигоди, а діє відповідно до принципів інноваційності, ініціативності та соціальної відповідальності: «соціальний підприємець поєднує в собі пристрасть до реалізації соціальної місії з іміджем ділової дисципліни, інновацій та рішучості» [1].

Питанню дослідження соціального підприємництва приділяли: Г. Діс, Ч. Лідбітер, Д. Борнштайн, Дж. Томпсон, Дж. Елві, Е. Лі, С. Захра, С. Брінкерхофф, С. Петер, Б. Дрейтон, Дж. Майр та I. Марті, А. Передо, М. Маклін, С. Алворд, Л. Браун, К. Леттс та ін.

Однак вчені ототожнюють визначення «Соціальний підприємець», «Соціальне підприємництво», «Благодійна організація» та не здійснюють оцінку ефективності впливу від такої діяльності на ОТГ, міста, регіон, країну. Важливість врахування регіональних особливостей підтримки соціального підприємництва пов'язана 3 тим, що соціальне підприємництво реалізовується на місцевому рівні, а також допомагає задіяти наявний підприємницький потенціал як резерв регіонального розвитку.

Цілі статті дослідити поняття соціального підприємництва, обгрунтувати відмінності від підприємницької діяльності, визначити ефекти розвитку регіональної економіки.

Виклад основного матеріалу дослідження 3 повним обгрунтуванням отриманих наукових результатів. Перші спогади про соціальне підприємництво з'явилися у 1960-х роках. У Великій Британії автором соціального підприємства $\epsilon$ Ф. Найтінгейл, яка заснувала перше училище для медсестер, а у 2004 році в Стенфордському університеті було створено соціальну електронну лабораторію в межах вивчення курсу «Підтримка підприємницької діяльності» із застосуванням принципів підприємництва щодо вирішення соціальних та екологічних проблем [1]. 
Економічні науки: збірник наукових праџь Луцького національного технічного університету. - Серія "Регіональна економіка". - Випуск 15 (59). - Редкол.: відп. ред. д.е.н., професор Л.Л. Ковальська. - Луцьк: ІВВ Луцьького НТУ, 2018. - 292 с.

Успішні соціальні проекти дозволяють вирішити окремі локальні проблеми на певних територіях, де вони виникають. Соціальне підприємництво сприяє розв'язанню складних соціальних проблем, які неспроможні на певний проміжок часу забезпечити державні та територіальні органи управління.

Науковці трактують поняття «соціальний підприємець» та «соціальне підприємництво» за різними підходами, тому доцільно охарактеризувати їх та виокремити можливі ефекти від діяльності соціального підприємства на регіональний розвиток.

Так, Г.Діс надає визначенню соціального підприємництва через порівняння п’яти факторів [2]: прийняття на себе місії створення і підтримки соціальної цінності (блага); невпинне використання нових можливостей для реалізації вибраної місії; безперервного процесу інновацій, адаптації та навчання; рішучість дій, що не обмежена наявними ресурсами; відповідальності підприємця за результати своєї діяльності.

Погоджуємось, що соціальна місія $\epsilon$ основною для соціального підприємництва, оскільки воно розпізнає та оцінює можливості розвитку суспільства. А робота соціального підприємця полягає у виявленні та вирішенні проблем шляхом зміни стереотипів соціальної системи. Відповідно, реалізація місії соціального підприємництва на певній території призведе до посилення соціальних процесів, взаємодія яких створюватиме синергічний соціальний ефект у створенні, розподілі, обміні та споживанні ВРП.

Ч. Лідбітер вважав, що соціальні підприємці - це інноваційні та «трансформаційні» суб'єкти господарювання, які також є: лідерами, новаторами, менеджерами та оповідачами [3].

Відповідно до тверджень Ч. Лідбітера, соціальні підприємці визнають соціальну проблему на певній території (ОТГ, місто, регіон) i організовують управління підприємством 3 метою вирішення конкретних соціальних проблем. Якщо соціальний підприємець прогресивний та вирішує соціальні проблеми на регіональному рівні, то це забезпечить покращення виявлення, уникнення та управління соціальних проблем в країні. 
Економічні науки: збірник наукових праџь Луцького національного технічного університету. - Серія "Регіональна економіка". - Випуск 15 (59). - Редкол.: відп. ред. д.е.н., професор Л.Л. Ковальська. - Луиьк: ІВВ Луиького НТУ, 2018. - 292 с.

Як зазначав Д. Бронштайн, соціальний підприємець - це кваліфікований управлінець 3 інноваційною ідеєю, яка поєднує в собі творчість до вирішення проблем у реальному житті, має сильну етичну структуру та повністю сприймається своїм баченням змін [4].

Погоджуємось, що соціальний підприємець несе відповідальність перед суспільством в цілому, він винахідливий та оригінальний при вирішенні будь яких соціальних проблем. Це свідчить про те, що свідома, відповідальна робота соціального підприємця має значний вплив на свідомість населення, які здійснюватимуть свою діяльність на певній території.

Дж. Томсон, Дж. Елві та Е. Лі визначають соціальних підприємців як осіб, які усвідомлюють, де $\epsilon$ можливість задовольнити потребу, яку система державної соціальної допомоги не зможе, і які збирають разом необхідні ресурси (як правило, люди, часто на добровільних засадах, використовуючи власні фінансові та виробничі ресурси) та використовують їх для зміни розвитку регіональної економіки [5].

Соціальні підприємці сприяють задоволенню потреб населення, навіть якщо відсутні чи недостатня кількість ресурсів, безпосередньо важливим $є$ усвідомлення необхідності вирішення соціальних проблем економічного регіону. Це призводить до соціальних перетворень та сталого розвитку території.

С. Захра вважав, що соціальне підприємництво включає в себе застосування інноваційних інструментів задля визначення та використання можливостей створення нових підприємств чи управління існуючими організаціями для покращення соціального розвитку регіону. Відповідно, погоджуємось, що задоволення суспільних благ сприяє соціально-економічному прогресу регіонів та реалізовується соціальним підприємством.

С. Брінкерхофф та С. Петер зазначали, що соціальний підприємець - це суб'єкт господарювання, який готовий до ризику [7]. Ризики у соціальному підприємництві - це небезпека втрати підприємства при реалізації господарських рішень, стратегій, проектів, внаслідок конфліктів колективу підприємства або між підприємством та громадськістю. Конфлікти 3 
Економічні науки: збірник наукових праџь Луцького національного технічного університету. - Серія "Регіональна економіка". - Випуск 15 (59). - Редкол.: відп. ред. д.е.н., професор Л.Л. Ковальська. - Луцьк: ІВВ Луиького НТУ, 2018. - 292 с.

громадськістю виникають через розбіжність інтересів окремих соціальних груп та між цілями підприємства. Сучасний соціальний підприємець, здійснює свою діяльність 3 метою досягнення соціального ефекту, вирішення регіональних та державних проблем.

Б. Дрейтон вважає, що соціальні підприємці - це люди 3 інноваційними рішеннями найважливіших соціальних проблем суспільства [8]. Отже, соціальні підприємці є як стратегами, так і виконавцями, вони зацікавлені в практичній реалізації соціальної місії задля сталого розвитку регіону та держави.

Дж. Майр і I. Марті узагальнили визначення соціального підприємництва як процес створення вартості через поєднання ресурсів для реалізації можливостей, що стимулюють створення соціальної цінності, зумовлюють соціальні зміни або виявляють соціальні потреби. Ця концепція показує, що соціальне підприємництво - це підхід до управління бізнесами, який має схожості з підприємництвом, але має відмінності у формулюванні місії та мети діяльності, спрямовані на отримання соціального ефекту. Погоджуємось, що між соціальним та традиційним підприємництвом $є$ певні схожості, проте відмінностей більше, ніж зазначали Дж. Майр і I. Марті [9]. Соціальне підприємництво спрямоване, не тільки на соціальний ефект, а також на економічний та екологічний.

Як вважають А. Передо і М. Маклін, соціальне підприємництво здійснюється задля створення соціальної цінності, a не економічної, (що створюються іншими формами підприємництва) новим або відомим способом [10]. Вони стверджують, що у соціальному підприємництві використовують інновації із сприйняттям наявного ризику, при винахідливому підході до створення соціальної цінності.

Звичайно соціальне підприємництво має значний соціальний вплив на розвиток регіону та країни, проте економічний ефект також займає важливе місце. Це проявляється через збільшення конкуренції для традиційного бізнесу, оскільки діяльність соціального підприємництва приносить більший соціальний 
Економічні науки: збірник наукових праџь Луцького національного технічного університету. - Серія "Регіональна економіка". - Випуск 15 (59). - Редкол.: відп. ред. д.е.н., професор Л.Л. Ковальська. - Луцьк: ІВВ Луичького НТУ, 2018. - 292 с.

внесок для певної території, ніж інші форми підприємництва, які налаштовані лише на отримання економічного ефекту.

С. Алворд, Л. Браун та К. Леттс стверджують, що соціальне підприємництво є каталізатором соціальних перетворень, ніж це вимагає мета його здійснення і $€$ мобілізатором соціальних суб' єктів щодо втілення спільних цілей [11]. Відповідно, соціальна трансформація за твердженнями вчених складається 3 трьох типів змін, 3 якими пов'язане соціальне підприємництво: культурні, економічні та політичні.

Соціальне підприємництво через втілення культурних, економічних та політичних змін відіграє важливе значення для суспільства та слугує удосконаленню соціально-економічного розвитку.

3. Галушка стверджує, що соціальне підприємництво це усвідомлення суб'єкта ролі свого обов'язку перед суспільством, яке представлене розумінням його потреб як індивідуально цінних та перевага над груповими [12]. 3. Галушка вважає, що відмінність підприємництва від соціального полягає у прямому сприянні соціального підприємництва на зміни у суспільстві способами, які відмінні від благодійності.

Охарактеризувавши визначення вчених, зведемо їх основні постулати в таблиці 1 для виокремлення основних характеристик та ефектів від соціального підприємництва для регіональної економіки.

Отже, сутність соціального підприємництва та його значення для розвитку економіки регіону визначатиметься у створенні та пропонуванні ціннісної соціальної пропозиції суб'єктами господарювання, які потребують фінансових, матеріальних та трудових ресурсів, але 3 певних причин не підтримані територіальними та державними органами влади для його успішної реалізації.

Охарактеризуємо і обгрунтуємо основні спільні та відмінні риси між соціальним підприємництвом, підприємництвом та благодійністю. 
Економічні науки: збірник наукових праџь Луцького національного технічного університету. - Серія "Регіональна економіка". - Випуск 15 (59). - Редкол.: відп. ред. д.е.н., професор Л.Л. Ковальська. - Луцьк: ІВВ Луиького НТУ, 2018. - 292 с.

Таблиця 1

Основні характеристики термінів «соціальний підприємець» та «соціальне підприємництво» та ефекти від їх діяльності на

\begin{tabular}{|c|c|c|}
\hline Термін, джерело & Основні характеристики & \begin{tabular}{|c|}
$\begin{array}{c}\text { Ефект для регіональної } \\
\text { економіки }\end{array}$ \\
\end{tabular} \\
\hline $\begin{array}{c}\text { Соціальний } \\
\text { підприємець [2] }\end{array}$ & $\begin{array}{l}\text { Менеджер } \\
\text { Лідер }\end{array}$ & Соціальний \\
\hline $\begin{array}{c}\text { Соціальне } \\
\text { підприємництво [3] }\end{array}$ & $\begin{array}{c}\text { Особливо відповідальний } \\
\text { Рішучий } \\
\text { Соціально обережний }\end{array}$ & Соціальний \\
\hline $\begin{array}{c}\text { Соціальний } \\
\text { підприємець [4] }\end{array}$ & $\begin{array}{c}\text { Лідер місії } \\
\text { Стійкий }\end{array}$ & Соціальний \\
\hline $\begin{array}{c}\text { Соціальний } \\
\text { підприємець [5] }\end{array}$ & $\begin{array}{c}\text { Емоційно заряджений } \\
\text { Соціальна цінність Творець }\end{array}$ & $\begin{array}{l}\text { Соціально- } \\
\text { економічний }\end{array}$ \\
\hline $\begin{array}{c}\text { Соціальне } \\
\text { підприємництво [6] }\end{array}$ & $\begin{array}{c}\text { Інноватор } \\
\text { Ініціативний приймач }\end{array}$ & $\begin{array}{l}\text { Соціально- } \\
\text { економічний }\end{array}$ \\
\hline $\begin{array}{c}\text { Соціальний } \\
\text { підприємець [7] }\end{array}$ & $\begin{array}{l}\text { Опікун } \\
\text { Лідер }\end{array}$ & $\begin{array}{l}\text { Соціально- } \\
\text { економічний }\end{array}$ \\
\hline $\begin{array}{c}\text { Соціальний } \\
\text { підприємець [8] }\end{array}$ & $\begin{array}{c}\text { Погляд } \\
\text { Виконано }\end{array}$ & Соціальний \\
\hline $\begin{array}{c}\text { Соціальне } \\
\text { підприємництво [9] }\end{array}$ & Бізнес-підхід & $\begin{array}{l}\text { Соціально- } \\
\text { економічний }\end{array}$ \\
\hline $\begin{array}{c}\text { Соціальне } \\
\text { підприємництво [10] }\end{array}$ & $\begin{array}{c}\text { Соціальна цінність } \\
\text { Винахідливість } \\
\end{array}$ & Соціальний \\
\hline $\begin{array}{c}\text { Соціальне } \\
\text { підприємництво [11] }\end{array}$ & Соціальні перетворення & Соціальний \\
\hline $\begin{array}{c}\text { Соціальне } \\
\text { підприємництво [12] }\end{array}$ & \begin{tabular}{|c|} 
Обов’язок перед суспільством \\
Індивідуальна цінність
\end{tabular} & Соціальний \\
\hline
\end{tabular}

Примітка. Розроблено автором.

Соціальне підприємництво, яке реалізовується на території певного регіону, спрямоване на пом'якшення або вирішення соціальних проблем. Отже, реалізація соціального підприємництва здійснюватиме такі впливи на економіку регіону: створення робочих місць; нових форм підприємництва; мінімізацію соціальної ізольованості фізичних осіб; активізації соціального партнерства, залучення до участі, зміцнюючи, таким чином, єдність громади, міста; удосконалення процесу створення та надання соціальних послуг; зниження навантаження на місцеві 
Економічні науки: збірник наукових праџь Луцького національного технічного університету. - Серія "Регіональна економіка". - Випуск 15 (59). - Редкол.: відп. ред. д.е.н., професор Л.Л. Ковальська. - Луцьк: ІВВ Луиького НТУ, 2018. - 292 с.

бюджети за рахунок використання інших джерел у вирішенні соціальних проблем; збільшення резервів фінансування соціальних програм регіону; збільшення ефектів соціальної дії з регіонального на національний та міжнародний рівні.

Отже, метою соціального підприємництва $є$ вирішення соціальних проблем, які виникають в громаді, місті, регіоні. Прибутки соціального підприємства спрямовуються на його подальший розвиток та на цілі соціальної економіки регіону. Таке соціальне підприємство буде здійснювати свою діяльність відповідно до законів економіки, з метою отримання прибутку, а тому не вважатиметься благодійною організацією.

Соціальне підприємництво припускає два типи господарювання, як i власне, підприємництво та благодійна діяльність: здійснення безпосередньо виробничих функцій; здійснення посередницьких функцій.

За формою власності розрізняють такі види підприємництва: приватне; державне; змішане.

За національною належністю капіталу: національне; закордонне; змішане; транснаціональне.

За організаційно-правовою формою господарювання: одноосібне; кооперативне; селянське (фермерське); господарські товариства; підприємницькі об'єднання.

За розміром: велике; середнє; мале; мікро-підприємство.

За сферою господарювання: виробниче; торговельне; посередницьке; фінансове; страхове; консалтингове; аудиторське тощо.

Пріоритетне значення має соціальна підприємницька діяльність, яка потребуе залучення різних факторів i характеризується тривалішим періодом від зародження бізнес-ідеї до реалізації виробленої продукції та отримання економічного, соціального, екологічного ефекту. Вибір конкретної сфери соціальної підприємницької діяльності пов'язане 3 потребою регіональної економіки, а також 3 потребами держави щодо певних видів діяльності. 
Економічні науки: збірник наукових праџь Луцького національного технічного університету. - Серія "Регіональна економіка". - Випуск 15 (59). - Редкол.: відп. ред. д.е.н., професор Л.Л. Ковальська. - Луцьк: ІВВ Луиького НТУ, 2018. - 292 с.

Основна відмінність між підприємництвом та соціальним підприємництвом не в мотивації, а у характері цінності, що отримується.

Отже, соціальне підприємництво здійснюється як 3 характеристиками підприємництва, так і благодійності, основні відмінності яких представимо у таблиці 2.

Таблиця 2

Основні відмінності соціального підприємництва від благодійної організації та традиційного бізнесу

\begin{tabular}{|c|c|c|c|}
\hline Ознаки & $\begin{array}{c}\text { Соціальне } \\
\text { підприємництво }\end{array}$ & Благодійна організація & Підприємництво \\
\hline 1 & 2 & 3 & 4 \\
\hline Тип діяльності & Соціальний & Соціальний & Комерційний \\
\hline $\begin{array}{c}\text { Отримання } \\
\text { прибутку }\end{array}$ & $\begin{array}{c}\text { Ніколи не розподіляють } \\
\text { прибуток і } \\
\text { використовують його } \\
\text { для соціальних цілей }\end{array}$ & Не має прибутку & $\begin{array}{c}\text { Отримання } \\
\text { прибутку }\end{array}$ \\
\hline $\begin{array}{c}\text { Сплата } \\
\text { податку }\end{array}$ & \begin{tabular}{|c} 
Соціальні підприємства \\
звільняються від \\
оподаткування \\
прибутку, отриманого \\
від продажу \\
(постачання) товарів та \\
виконання соціальних \\
робіт та послуг
\end{tabular} & $\begin{array}{c}\text { Не є платником податку } \\
\text { на прибуток та } \\
\text { включається до реєстру } \\
\text { неприбуткових установ } \\
\text { та організацій з ознакою } \\
\text { неприбутковості }\end{array}$ & $\begin{array}{c}\text { Прибуток } \\
\text { розподіляється } \\
\text { серед акціонерів }\end{array}$ \\
\hline $\begin{array}{c}\text { Вид } \\
\text { діяльності }\end{array}$ & $\begin{array}{c}\text { Соціальні } \\
\text { роботи та послуги }\end{array}$ & $\begin{array}{c}\text { Не здійснює } \\
\text { підприємницьку } \\
\text { діяльність }\end{array}$ & $\begin{array}{c}\text { Виробниче } \\
\text { підприємництво: } \\
\text { комерційне; } \\
\text { фінансове }\end{array}$ \\
\hline $\begin{array}{c}\text { Джерела } \\
\text { фінансування }\end{array}$ & $\begin{array}{c}\text { Не залежить від } \\
\text { зовнішніх джерел } \\
\text { фінансування } \\
\end{array}$ & $\begin{array}{c}\text { Зовнішні джерела } \\
\text { фінансування }\end{array}$ & $\begin{array}{l}\text { Зовнішні та } \\
\text { внутрішні } \\
\text { джерела }\end{array}$ \\
\hline $\begin{array}{c}\text { Мета } \\
\text { діяльності }\end{array}$ & \begin{tabular}{|c} 
Дохід від власної \\
діяльності, метою якої є \\
пом’якшення або \\
вирішення конкретних \\
соціальних проблем
\end{tabular} & $\begin{array}{c}\text { Гранти та пожертви, які } \\
\text { спрямовуються на } \\
\text { благодійну діяльність }\end{array}$ & $\begin{array}{c}\text { Дохід від власної } \\
\text { діяльності, } \\
\text { метою якої } \\
\text { є максимізація } \\
\text { прибутку }\end{array}$ \\
\hline
\end{tabular}

Примітка. Розроблено автором 
Економічні науки: збірник наукових праџь Луцького національного технічного університету. - Серія "Регіональна економіка". - Випуск 15 (59). - Редкол.: відп. ред. д.е.н., професор Л.Л. Ковальська. - Луцьк: ІВВ Луцького НТУ, 2018. - 292 с.

Соціальне підприємництво від благодійності отримує схожість за соціальною спрямованістю діяльності, а від бізнесу підприємницький підхід та можливість отримання прибутку для реінвестування інновацій.

Цікавими є критерії відношення підприємств до соціальних. В США, наприклад, достатньо, щоб товар або послуга вирішували певну соціальну проблему, і тоді підприємство, яке виробляє цей товар або надає послугу, вже можна називати соціальним. В Європі соціальні підприємства мають віддавати частину прибутку на соціальні проекти або надавати роботу людям 3 особливими потребами. Проте існує один критерій, з яким погоджуються всі це соціальний ефект, який має бути вимірюваним.

Закономірною основою пізнання сутності становлення та розвитку соціального підприємництва $є$ удосконалення підходу до формування регіональної економічної політики на основі теоретичних, науково-обумовлених законів та закономірностей розвитку продуктивних сил і регіональної економіки.

Соціальне підприємництво важливо розглядати як один із найбільш пріоритетних напрямів діяльності територіальних органів влади щодо забезпечення соціально-економічного розвитку регіону.

У таблиці 3 наведемо ефекти соціального підприємництва та їх значення для розвитку регіональної економіки.

Таблиця 3

Ефекти соціального підприємництва та їх значення для регіонального розвитку

\begin{tabular}{|c|c|}
\hline Типи ефектів & Значення \\
\hline 1 & 2 \\
\hline$\left|\begin{array}{c}\text { Економічний } \\
\text { ефект }\end{array}\right|$ & $\begin{array}{l}\text { Виробництво товарів та послуг; } \\
\text { сприяння підприємництву; } \\
\text { фінансування за допомогою грантів (наприклад, від фондів) } \\
\text { та позик із низьким відсотком (наприклад, від кредитних } \\
\text { спілок); } \\
\text { сприяння підприємствам з низьким рівнем приватного } \\
\text { підприємництва; } \\
\text { створення альтернативної вартості }\end{array}$ \\
\hline
\end{tabular}


Економічні науки: збірник наукових праць Луиького національного технічного університету. - Серія "Регіональна економіка". - Випуск 15 (59). - Редкол.: відп. ред. д.е.н., професор Л.Л. Ковальська. - Луиьк: ІВВ Луиького НТУ, 2018. - 292 с.

\begin{tabular}{|c|c|}
\hline 1 & 2 \\
\hline $\begin{array}{c}\text { Соціальний } \\
\text { ефект }\end{array}$ & $\begin{array}{l}\text { Створення зайнятості для людей з обмеженими фізичними } \\
\text { та психічними можливостями; } \\
\text { заохочення інноваційних послуг та впровадження нових або } \\
\text { покращених послуг; } \\
\text { розвиток альтернативних бізнес-моделей соціальних послуг; } \\
\text { сприяння соціальній інтеграції, соціальній єдності та } \\
\text { формування соціального капіталу; } \\
\text { демократична участь та залучення громадянства; } \\
\text { сприяння розвитку культурних територіальних цінностей; } \\
\text { сприяння мистецьким та спортивним заходам }\end{array}$ \\
\hline $\begin{array}{c}\text { Екологічний } \\
\text { ефект }\end{array}$ & $\begin{array}{l}\text { Заохочення розвитку екологічної стійкості; } \\
\text { врахування обмеженості природних ресурсів, їх ощадливе } \\
\text { використання і розвиток суспільного виробництва; } \\
\text { формування комплексу заходів щодо ліквідації забруднення } \\
\text { середовища для подальшого розвитку суспільства; } \\
\text { захист навколишнього середовища }\end{array}$ \\
\hline
\end{tabular}

Існує необхідність продовження дослідження механізмів стимулювання розвитку соціального підприємництва, виявлення чинників реалізації їх потенціалу щодо вирішення соціальноекономічних проблем.

Висновки. Соціальне підприємництво - це діяльність суб' єкта господарювання на певній території, метою якого є виявлення та вирішення соціальних проблем, що здійснюється за умови інноваційності, креативності, самофінансування. Це нова форма підприємництва, яка забезпечує досягнення соціальних, економічних та екологічних цілей. Соціальне підприємництво характеризується соціальною спрямованістю від благодійності, а підприємницькою - від бізнесу. Соціальні підприємці в регіоні реалізовують діяльність 3 врахуванням соціально-економічних інтересів та потреб населення, громади.

1. Abu-Saifan S. (2012) Social Entrepreneurship: Definition and Boundaries. Technology Innovation Management Review. February 2012. 22-27 
Економічні науки: збірник наукових праџь Луцького національного технічного університету. - Серія "Регіональна економіка". - Випуск 15 (59). - Редкол.: відп. ред. д.е.н., професор Л.Л. Ковальська. - Луиьк: ІВВ Луиького НТУ, 2018. - 292 с.

2. Дис Г.Дж. Лаборатория знаний [Електронний ресурс] / Г.Дж. Дис //Финансы и развитие, ежеквартальный журнал Международного валютного фонда. - Декабрь, 2012. - Вип. 49.

3. C. Leadbeater (1997) The Rise of the Social Entrepreneur, Demos, London.

4. Bornstein D. (1998) Changing the World on a Shoestring. The Atlantic Monthly, Vol. 281, No. 1, 34-39.

5. John Thompson, Geoff Alvy, Ann Lees. (2000) Social entrepreneurship - a new look at the people and the potential, Management Decision, Vol. 38, 328-338. https://doi.org/10.1108/0025174001034051

6. Shaker A. Zahra, Hans N. Rawhouser, Nachiket Bhawe, Donald O. Neubaum, James C. Hayton (2008) Globalization of social entrepreneurship opportunities. Vol. 2, 117-131.

7. Brinckerhoff C., Peter C. (2000) Social entrepreneurship: the art of missionbased venture development. New York: Wiley. Vol. 238, 35-42.

8. Електронний ресурс. - Режим доступу: http://www.egonzehnder.com/files/drayton_int_2_1.pdf

9. Mair J., Marti I. (2006) Social entrepreneurship research: A source of explanation, prediction, and delight. No41(1). 37-41.

10. Peredo A.M. (2006) Social entrepreneurship: A critical review of the concept. Journal of World Business. No 41(1). 56-65.

11. Sarah H. Alvord, L. David Brown, Christine W. Letts. (2004) Social Entrepreneurship and Societal Transformation: An Exploratory Study. The Journal of Applied Behavioral Science. https://doi.org/10.1177/0021886304266847

12. Галушка 3.I. Феномен соціального підприємництва: поняття та перспективи розвитку в Україні / 3.І. Галушка // Вісник серія Економіка. - К.: ВПЦ «Київський національнй університет» №148. - 2013. - С. 17. 